\title{
Analyzing Museum Visitor Experiences and Post Experience Dimensions Using SEM ${ }^{*}$
}

\author{
Taşkın Dirsehan** \\ Marmara University
}

\begin{abstract}
In marketing strategies, the consumer-focus approach reveals customer experience management as a differentiating tool for competitive advantage in an increasingly competitive environment. In recent years, museums compete with other leisure and educational institutions such as other museums, theatres, cinemas and amusement parks. Thus, customer experience management provides a competitive advantage for museums.

This study aims to reveal the effects of customer experiences from the museum perspective. For this purpose, an exploratory research and a descriptive research are conducted in Istanbul. Based on the research findings, a structural equation model is developed to reveal the relationships between customer experiences and post experience dimensions (learning in museum, visitor satisfaction, visit intensification, word-of-mouth communication and revisit intention).
\end{abstract}

Keywords: customer experience management, experiential marketing, museum marketing, Structural Equation Model.

\section{Müze Ziyaretçi Deneyimlerinin ve Deneyim Sonrası Boyutların YEM Kullanılarak Incelenmesi}

\section{Özet}

Pazarlama stratejilerinde tüketici odaklı yaklaşım, tüketici deneyimi yönetimini artan rekabet ortamında farklılaştırıcı bir araç olarak ortaya çıkarmaktadır. Son yıllarda, müzeler; diğer müzeler, tiyatrolar, sinemalar ve eğlence parkları gibi diğer eğitici ve boş vakitleri değerlendirmeye yönelik kurumlarla rekabet etmektedir. Dolayısıyla, tüketici deneyimi yönetimi müzeler için rekabet avantajı sağlamaktadır.

$\mathrm{Bu}$ çalışma, müze perspektifinden tüketici deneyimlerinin etkilerini ortaya çıarmayı amaçlamaktadır. Bu amaçla, İstanbul'da bir keşfedici araştırma ve bir tanımlayıcı araştırma yürütülmüştür. Araştırma sonuçlarını temel alarak, tüketici deneyimleri ve deneyim sonrası boyutlar (müzede öğrenme, ziyaretçi memnuniyeti, ziyareti kuvvetlendirme, kulaktan kulağa iletişim ve tekrar ziyaret niyeti) arasındaki ilişkileri ortaya çıkarmak için bir yapısal eşitlik modeli geliştirilmiştir.

Anahtar kelimeler: tüketici deneyimi yönetimi, deneyimsel pazarlama, müze pazarlaması, Yapısal Eşitlik Modeli.

This article is derived from Taşkın Dirsehan's unpublished master thesis accepted by the Institute of Social Sciences of Marmara University in June 2011. The author expresses his thank his thesis advisor, Associate Professor A. Müge Yalçın for her valuable and consistent advices.

** Taşkın Dirsehan is a research assistant in the Faculty of Business Administration at Marmara University, Anadolu Hisarı Campus, Beykoz, Istanbul, Turkey. E-mail: taskin.dirsehan@marmara.edu.tr 
$\mathrm{T}$ The evolution of marketing is based on the increasing competition from an era where every product has its waiting consumers to an era where the supply greatly exceeds the demand. The strategies of organizations change also in each era in order to succeed in dynamic markets (Gentile et al., 2007; Keith, 1960; Kotler et al., 1999; Kurtz and Boone, 2010). Accordingly, consumers' behaviors change with this evolution. Nowadays, they do not seek only functional benefits but they relate to products as a result of their feelings towards them (Schmitt, 1999). Considering this change, as a competitive advantage experiential marketing focuses on the emotional sides in addition to the customers' rational sides in order to create positive and memorable customer experiences (Berry et al., 2002; Dirsehan, 2010; McCarthy and Ciolfi, 2008; Meyer and Schwager, 2007; Schmitt, 1999; Shaw, 2007; Yalçın, 2009).

Traditional marketing defines the consumers as rational decision makers concerning functional features and benefits of products. On the other hand, experiential marketing views consumers' rational and emotional sides considering their concern to achieve pleasurable experiences (Schmitt, 1999). In comparison with goods, service offerings have naturally more potential to offer memorable experiences. So, museums, as being a part of the service sector, can create memorable positive experiences for their visitors using experiential marketing strategies as competitive tools.

The museums are institutions that keep alive the cultural assets of societies. Traditionally, they focus on their collection and research. However in recent years, museums compete with other museums and also other leisure and educational institutions (Bergadàa, 2005; Lehn, 2006). Some examples of these institutions can be listed as theatres, movie theatres, malls, circuses and amusement parks. So, museums need to compete with them using marketing strategies and they now focus more on attracting visitors. This situation creates a shift from traditional "curators' dictation" to "visitor orientation." Therefore, museum managers need a change in their marketing strategies.

The change mentioned above is about the presentation of experiences to museum visitors. Today, as a key concept in consumer culture theory, the experience (Arnould and Thompson, 2005) has become the basis for experience economy (Pine and Gilmore, 1998), and then experiential marketing is developed (Schmitt, 1999) for differentiation with experiences rather than commoditized goods and services. Thus, museums should create experiences that distinguish them from their competitors (other museums and other places for leisure time activities).

There are several studies in the literature about customer experiences and museums. The study of Harrison and Shaw (2004) tests the relationship of service elements (facilities, staff services and experience) with satisfaction and intentions (to return and to recommend) in a museum concept. They use a 6-item experience construct as a performance element (educational, stimulating, relevant, authentic, contemplative and emotive). They show that the experience is the most important variable in developing the satisfaction (Harrison and Shaw, 2004). In terms of measuring experiences, this research refers to the study of Brakus et al. (2009) who develop five dimensions to measure customer experiences (sensory, affective, creative cognitive, physical and social) on various brands. Their model reveals that brand experience has a direct ef- 
fect on brand personality, satisfaction and loyalty. Additionally, they show that brand experience affects customer satisfaction through brand personality, brand loyalty and satisfaction (Brakus et al., 2009).

This study pioneers in measuring customer experiences with its dimensions and its effects on post experience dimensions in Turkish museums. The research mainly investigates the outcomes of museum visitor experiences. With this purpose, eight museums dynamic in experiences are chosen for the research. According to 460 participants' responses, a structural equation modeling is proposed to reveal the effects of customer experiences (sensory, affective, creative cognitive, physical, social) on post experience dimensions (learning in the museum, visitor satisfaction, WOM communication, revisit intention and intensification of the visit). Since there is no previous research for this subject in Turkey, an exploratory research in the form of an in-depth interview takes precedence over the quantitative one.

\section{Experiential Marketing: The Emerging Concept in Marketing}

Compared with the traditional approach in marketing research, the consumer behavior is far more complex in sensory, imaginative and emotional perspectives. The multiple sides of the consumption experience can be comprehended with the hedonic approach (Hirschman and Holbrook, 1982).

Considering the complex nature of consumer behavior, businesses may have a competitive advantage with their understanding of the customers' needs and their experience of paying attention to the customer value (Chou, 2009). They should consider also that in some instances, emotional desires dominate utilitarian motives in the choice of products (Maslow, 1968). Accordingly, as a tool to create a competitive advantage, experiential marketing, an emerging concept in the field of marketing, aims to create positive and memorable customer experiences to create an emotional tie with them.

In terms of consumer-organization interaction, the consumption experience is a response to a corporate stimulus taking forms of sensory, affective, creative cognitive, physical and social identity (Zarantonello, 2008). From a business perspective, "experiences are events that engage individuals in a personal way" (Pine and Gilmore, 1999). From the consumers' perspective, "experiences are enjoyable, engaging, memorable encounters for those consuming these events" (Oh et al., 2007).

The notion of experience has become a key element in understanding consumer behavior and is the basis of experiential marketing (Carù and Cova, 2006). Today, the experience is considered a key concept in consumer culture theory (Arnould and Thompson, 2005). It has become the basis for experience economy (Pine and Gilmore, 1998), and then experiential marketing is developed (Schmitt, 1999) proposing differentiation with experiences rather than commoditized goods and services.

"Experience involves acting and being acted upon, sensing and feeling both, and transforming them into something emotionally and intellectually meaningful" (McCarthy and Ciolfi, 2008). Anything that can be perceived, sensed or noticed by its absence represents an experience clue carrying a message. The composition of all the clues forms the customer's total experience (Berry et al., 2002). 
Schmitt (1999) proposes five strategic experience modules which are defined as follows: 1) Sensory Experience or SENSE Marketing appeals to the senses with the objective of creating sensory experiences, through sight, sound, touch, taste and smell; 2) affective experience or FEEL Marketing appeals to customers' inner feelings and emotions, with the objective of creating affective experiences that range from mildly positive moods linked to a brand to strong emotions of joy and pride; 3 ) creative cognitive experience or THINK Marketing appeals to the intellect with the objective of creating cognitive, problem-solving experiences that engage customers creatively; 4) ACT Marketing which can be identified by physical experiences, behaviors and lifestyles enriches customers' lives by targeting their physical experiences showing them alternative ways of doing things, alternative lifestyles and interactions; 5) social identity experience or RELATE Marketing contains aspects of SENSES, FEEL, THINK and ACT marketing. However, RELATE marketing expands beyond the individual's personal, private feelings, thus relating the individual to something outside his/her private state (Schmitt, 1999).

\section{The Evolution of Museum Marketing}

In the classic approach, a museum is an institution charged particularly with the conservation of finds such as historical or archeological ones having a primary objective of spreading the knowledge (Bifulco and Ilario, 2007). In Turkey, the museums' (except the private ones) main source of revenue is the share determined by the Ministry of Culture and Tourism. In some museums, there are divisions selling gifts and souvenirs. For funds for restoration, museums try to find sponsorships from the private sector. So, museums are lacking in the budget to cover personnel, educational activities and technological tools (Aktekin, 2008). Thus, museums (including private ones) have to finance themselves. The basic management issues for museums include a decision to introduce admission charges, ways to increase the number of visitors, and improving the experience of the museum visit. These decisions require the understanding of the public, both visitors and non-visitors (Kawashima, 1998).

Among the various methods and techniques used to manage the museums effectively are marketing methods and techniques. The reasons for marketing entry into museology are the growth of museums and the increasing competition (Sezgin and Karaman, 2009). For museums, marketing is an exchange process among consumers, museums and competitors. If the value offered by museums is high enough (if the benefits exceed the costs), they expect that a consumer will respond positively to a museum and its offerings (Kotler et al., 2008).

In the 20th century, museums often were concerned with collection and research than visitor-orientation. In recent years, museums are competing increasingly for visitors with other leisure and educational institutions such as different cultural museums (Bergadàa, 2005; Lehn, 2006). Accordingly, museums today are expected to focus on visitors rather than to lecture the public from the curators' point of view (Chang, 2006; Goulding, 2000; Harrison and Shaw, 2004; Lehn, 2006; Rowley, 1999). In this way, the need to understand the museum experience has gained ground (Goulding, 2000). However, the researches in the museum marketing area mainly focus on visitor profiling 
including demographics such as age, education, place of residence and nationality in order to determine who visits the museums (Harrison and Shaw, 2004). For instance, it is often found that a strong correlation exists between the socio-economic class of a visitor and the habit of museum visiting (Kawashima, 1998). But in today's competitive environment, the focus of museums' marketing techniques shape the messages about the products and experiences delivered by museums (Caldwell, 2000). Within the marketing field of cultural heritage, the concept of experience becomes a key leading to consumer satisfaction. Consumers seek a "total experience," where leisure, culture, education and social interaction can be included (Rojas and Camarrero, 2006).

Parallel to the development of experience in museum contexts, the audience research in the literature also is increasingly focused on visitor experiences and learning (Kelly, 2004). In terms of visitor studies, the focus is often the educational role of museums and the learning outcome of museum visits while ignoring other aspects of the museum experience (Lehn, 2006). The recent research on museum consumer behavior reveals that museum visits are no longer simple informative cultural visits, but they are experiences (Bollo, 2004; Falk and Dierking, 1992; Goulding, 1999; Hume et al., 2006; Kawashima, 1998; Prentice et al., 1997; Thyne, 2001; Rojas and Camarrero, 2006; Slater, 2007).

Related to their role of service experience consumption, museums can be defined as experience-centered places that offer both emotional and cognitive stimuli. Thus, an understanding of visitor experiences is vital for museums focusing on visitors and experiences (Chang, 2006) and they are important assets for policy analysis and managerial implications (Yucelt, 2000) because the dimensions of customer experience leading to satisfying the customers help a firm to increase its competitiveness (Högström et al., 2010).

\section{Museum Experiences as an Emerging Concept}

Customers seek different services or products from the museums (Rowley, 1999). The service sector may create experiences in two ways: They may be experiential by nature or they may devise additional experiences for their core service. Having an experiential offering is different from actively and deliberately marketing that offering in an experiential way (Petkus, 2004).

Focusing on experiential marketing, the main point to consider is that the total customer experience is different for each customer (Rowley, 1999). The interactive experience model of Falk and Dierking (1992), based on museum experience, shows us that all experience includes three contexts:

1) The personal context which includes motivations, expectations, interests, beliefs, prior knowledge and experiences,

2) The social context which includes social interactions within groups and between visitors and staff, and

3) The physical context which includes institutional rules, architecture, layout, activities and facilities.

The interactive experience model involves the interplay of these three contexts. This model explains that each of these contexts is constructed by the visitor and the 
interaction of them creates the visitor's experience. This constructed reality is unique to the individual; therefore two different people never see the world in the same way. For instance, three people in a dark room each focusing on the same object with their own insights will illuminate differently the object because of the difference of their beams (personal context), the difference of their angle of light (physical context), and the benefits of shared light (social context) (Falk and Dierking, 1992). Hence, the consumers have their own experiences that differ from each other's (Chang, 2006).

Experiences from one visitor to another are different because museum visitors construct their own meanings within museums. Museum experience is personal rather than standard due to the visitors' different expectations (Chang, 2006), previous museum experiences (Chang, 2006; McCarthy and Ciolfi, 2008), level of perceptual skills (Chang, 2006), lifestyle (Tucker, 1991) and cultures (McCarthy and Ciolfi, 2008). These factors vary depending on customers and this makes the experiences individualized for each one.

Another factor of a personal nature of experience is the social environment in museums. Museums are public places where people even when arriving on their own often meet others exploring the exhibition at the same time (Lehn, 2006). However, the approach and viewing of the exhibits often occurs in social interaction with others, companions and also strangers (Lehn, 2006). This social nature of the visit includes verbal exchanges (such as asking for and giving information) and nonverbal influences affecting visitor's behavior in visiting an exhibit or moving elsewhere (Bitgood, 1993). Discussion of an experience with others can color the experience (McCarthy and Ciolfi, 2008). Visitors' observation of others provides them with ideas on what can be done at an exhibit and what kind of experience they can expect to have (Lehn, 2006).

Considering all of the factors in experience management, visitors' museum experiences should be memorable experiences that lead visitors to future museum participation and increased learning, appreciation and enjoyment (Chang, 2006).

\section{Post Experience Dimensions}

Post experience dimensions include learning acquired in museums, customer satisfaction, repurchase intention, word-of-mouth recommendation and visit intensification.

\section{Learning in Museums}

Profit-oriented firms generally use financial measures to evaluate their performance. However, a non-profit organization's performance is measured in both financial and nonfinancial terms, in other words, in raising the funds and educating the public (Mottner and Ford, 2005). Different kinds of museums promote different kinds of learning experience with attention to knowledge gain and thinking (Donald, 1991). Museums, art galleries, botanical gardens, national parks, science centers, zoos, aquaria and historic sites are important institutions for their public educational role; however, it cannot be assumed that all the visitors to these institutions come there to learn something; a large percentage of visitors are there to kill time, to be entertained, and to satisfy their curiosity (Packer and Ballantyne, 2002). 


\section{Customer Satisfaction}

Satisfaction is the customer's evaluation of a product or service concerning whether that product or service has met the customer's needs and expectations. Failure to meet needs and expectations is assumed to result in dissatisfaction with that product or service (Zeithaml et al., 2009). In other words, if the performance distinct from expectations, a positive disconfirmation is produced and an increase in satisfaction level is expected (Rojas and Camarrero, 2006). Customer expectations can be shaped by customers' previous experiences, their personal situation, market conditions and the competition. In terms of customer experiences, the customer satisfaction can be defined as the net result of the good ones minus the bad ones (Meyer and Schwager, 2007). Considering the gap between the consumption experience and prior expectations, as mentioned before, the satisfaction is, to quote Oliver (1981) :

"The summary psychological state resulting when the emotion surrounding disconfirmed expectations is coupled with the consumer's prior feelings about the consumption experience."

Satisfaction is a significant antecedent for the post-purchase attitude, the intentions of repurchase and other good behavioral intentions (Anderson and Sullivan, 1993; Cronin and Taylor, 1992; Fornell, 1992).

\section{Repurchase Intention}

If a consumer is satisfied with a product of a certain company, generally that consumer buys the product again, intends to recommend it to other people, ignores competitors' brands' advertisements and stops purchasing from competitors (Chou, 2009). Repurchase intention is often confused with loyalty. Loyalty is the commitment to repurchase a particular product or service over time, while repurchase intention is the intention to engage in re-buying in the actual behavior (Hume et al., 2006). However, loyalty, a consequence of satisfaction in the business field, is not a priority for cultural organizations since the purpose is not that the visitor repeats the visit too often. So, other results of satisfaction are important such as word of mouth communication, the recommendation of services and the intensification of its use (Rojas and Camarrero, 2006).

\section{Word-of-Mouth Recommendation}

A satisfied customer intends to recommend the product to other people. Moreover, service consumers are influenced by other people's opinions. Hence, understanding word-of-mouth communication and its control are important for companies offering services (Zeithaml, 1996). Satisfaction with the service from a previous experience becomes positive word of mouth communication about the company (Bearden and Teel, 1983; Woodside et al., 1989). The best way to get positive word of mouth is to create memorable and positive service experiences (Zeithaml, 1996).

The average customer who has had a problem tells 9 or 10 others about it (Evans, 1997). Similarly, as stated in the study of Harrison and Shaw (2004) on museums, satisfied visitors intend to recommend them to other people. Thus, museums should consider implementing memorable and positive experiences not only for customer satisfaction but also for positive word of mouth communication. 


\section{Visit Intensification}

When compared with long-term behavioral intentions such as loyalty, consumers have also immediate behavioral responses such as their efforts to make the experience tangible with a purchase of souvenirs and gifts (Bigné et al., 2008). As one of the visitor's satisfaction results, the intensification of the visit can be defined as an interest or motivation by the visitor or as a behavioral intention including the purchase of publications, souvenirs and presents. Satisfied visitors intensify their experience during the service and they purchase concrete materials connected to the visit (Rojas and Camarrero, 2006). Thus, museum managers should consider the materials to sell in order to intensify the visitors' experience. As mentioned before, tangible takeaways such as programmes, souvenirs, prints and gifts are used in creating memorable experience. More innovative, personalized, customized memorabilia will enhance their value (Petkus, 2004).

\section{Classification of Museums}

A classification of museums is determined considering their different aspects. It can be based on their contents, on their civilizations and on their eras. The classification of museums according to their contents includes anthropological museums (archaeological, ethnographic, folkloric); history (social history, war, migration); art and modern art; natural art and nature; science, technical and industry and specialized museums (tree, automobile, wine, health, tobacco, textile, toy etc.). The classification of museums according to their civilizations in Turkey include Hittite civilization, Roman period, Byzantine period, Turkish-Islamic civilizations, Ottoman civilization, and Republic period museums. The classification of museums according to their eras include museums according to their items' eras: museums concerning prehistory, museums concerning the Lycian period, museums concerning the Hellenistic era, museums concerning the Neolithic era and museums concerning the modern age (Bilgin, 2010).

Another categorization of museums is based on the theory of education consisting of theory of knowledge and theory of learning. The theory of knowledge can be represented as a continuum since it involves a dichotomy of whether we believe that knowledge exists as an absolute and independent of the learner, or whether we subscribe to the view that knowledge consists only of ideas constructed in the mind. The second element which is theory of learning includes two possible extreme positions. One view is associated with the belief that the original condition of the mind is a tabula rasa and that all that is known has been acquired through experience. The best proponent of this view is Locke. The opposed view states that the mind constructs schemas and that learning consists of selecting and organizing from the abundance of sensations surrounding us. The combination of these two dimensions (a theory of knowledge and a theory of learning) generates a diagram. The four quadrants produced can be used to classify museums by their educational positions: systematic museums, discovery museums, orderly museums and constructivist museums (Hein, 1995). 
Aside from the above-mentioned bases of classifications for museums, an experiential perspective can be applied to categorize museums. As mentioned before, museums provide experiences by nature, especially the social interaction. However, they should go beyond to be differentiated by experiences. So, it is possible to categorize them as dynamic museums in experience and museums static in experience. In this context, museums using experience as a competitive tool can be considered in the group of dynamic museums in experience. In contrast, museums offering their natural experience rather than improving it to create a differentiation may be considered as static museums in experience. Based on this classification, museums that can be considered as dynamic museums in experience with their differentiating experiences can be summarized as seen in Table 1 . The museums which are static in experience are museums that always offer the same experience to their visitors. So, they do not offer dynamic experiences created by museum managers. The offered experience is the same but this experience is different for every customer due to the interactive nature of the experience as stated before; but the museums considered as dynamic in experience use their experiences to compete with each other and change with the museums' marketing strategy. These museums try to offer new experiences to their visitors as they take into account their feedback. So, the dynamic situation is created by museum experiences. The museums dynamic in experience are new in Turkey and general information about them is provided in the part on museums in Turkey in this study.

\section{Table 1}

\section{Dynamic Museums in Experience with their Differentiating Experiences}

\begin{tabular}{|c|c|}
\hline Museums & Examples of Differentiating Experiences \\
\hline Magic Ice Museum & $\begin{array}{l}\text { - Walking through and observing sculptures, walls and tunnels made of ice. } \\
\text { - Sitting on tables made of ice. } \\
\text { - Drinking fruit juice from glass of ice. } \\
\text { - Having education sessions on ice sculpture. }\end{array}$ \\
\hline $\begin{array}{l}1453 \text { Panorama } \\
\text { Museum }\end{array}$ & $\begin{array}{l}\text { - Watching the whole panoramic picture. } \\
\text { - Hearing different voices watching different part of the picture. } \\
\text { - Listening information about the museum offerings with earphones. }\end{array}$ \\
\hline $\begin{array}{l}\text { Istanbul Toy } \\
\text { Museum }\end{array}$ & $\begin{array}{l}\text { - Sitting on train chairs and hearing train voices in train room of the museum. } \\
\text { - Having red walls in fire-fighting room. } \\
\text { - Hearing particular voices for different rooms. } \\
\text { - Listening to information about the museum offerings with earphones. }\end{array}$ \\
\hline $\begin{array}{l}\text { Sakıp Sabancı } \\
\text { Museum }\end{array}$ & $\begin{array}{l}\text { - Having guidance. } \\
\text { - Having education sessions. } \\
\text { - Watching films related to the museum offerings. }\end{array}$ \\
\hline $\begin{array}{l}\text { Rahmi M. Koç } \\
\text { Museum }\end{array}$ & $\begin{array}{l}\text { - Having education sessions in studios. } \\
\text { - Participating in different weekend activities, for instance nostalgic rides } \\
\text { on railway along the shores of the Golden Horn. } \\
\text { - Participating in some exhibits to be entertained and be informed. }\end{array}$ \\
\hline Pera Museum & $\begin{array}{l}\text { - Having education sessions. } \\
\text { - Watching films related to museum offerings. }\end{array}$ \\
\hline $\begin{array}{l}\text { Istanbul Museum } \\
\text { of Modern Art }\end{array}$ & $\begin{array}{l}\text { - Having education sessions. } \\
\text { - Participating in special organizations. }\end{array}$ \\
\hline Miniaturk & - Observing different models of monuments from Turkish and Ottoman geography. \\
\hline
\end{tabular}




\section{Research Design and Methodology}

The research subject is intended to determine the effects of customer experiences on post experience dimensions in conjunction with the relationships among these dimensions. Based on the literature, the hypotheses are formed as follows:

$\mathbf{H}_{\mathbf{1}}$ : Customer experience has an effect on learning in the museum.

$\mathbf{H}_{2}$ : Learning in the museum has an effect on visitor satisfaction.

$\mathbf{H}_{3}$ : Customer experience has an effect on visitor satisfaction.

$\mathbf{H}_{4}$ : Visitor satisfaction has an effect on visit intensification.

$\mathbf{H}_{5}$ : Visitor satisfaction has an effect on visitor revisit intention.

$\mathbf{H}_{6}$ : Visitor satisfaction has an effect on word-of-mouth recommendation.

$\mathbf{H}_{7}$ : Learning in the museum has an effect on visit intensification.

$\mathbf{H}_{8}$ : Learning in the museum has an effect on visitor revisit intention.

$\mathbf{H}_{\mathbf{9}}$ : Learning in the museum has an effect on word-of-mouth recommendation.

$\mathbf{H}_{\mathbf{1 0}}$ : Customer experience has an effect on visit intensification.

$\mathbf{H}_{11}$ : Customer experience has an effect on visitor revisit intention.

$\mathbf{H}_{12}$ : Customer experience has an effect on word-of-mouth recommendation.

$\mathbf{H}_{13}$ : Learning in the museum has a mediating role for the effect of customer experiences on visitor satisfaction.

The model to be tested with research hypotheses is shown in the Figure 1.

Figure 1

Hypotheses of the Research

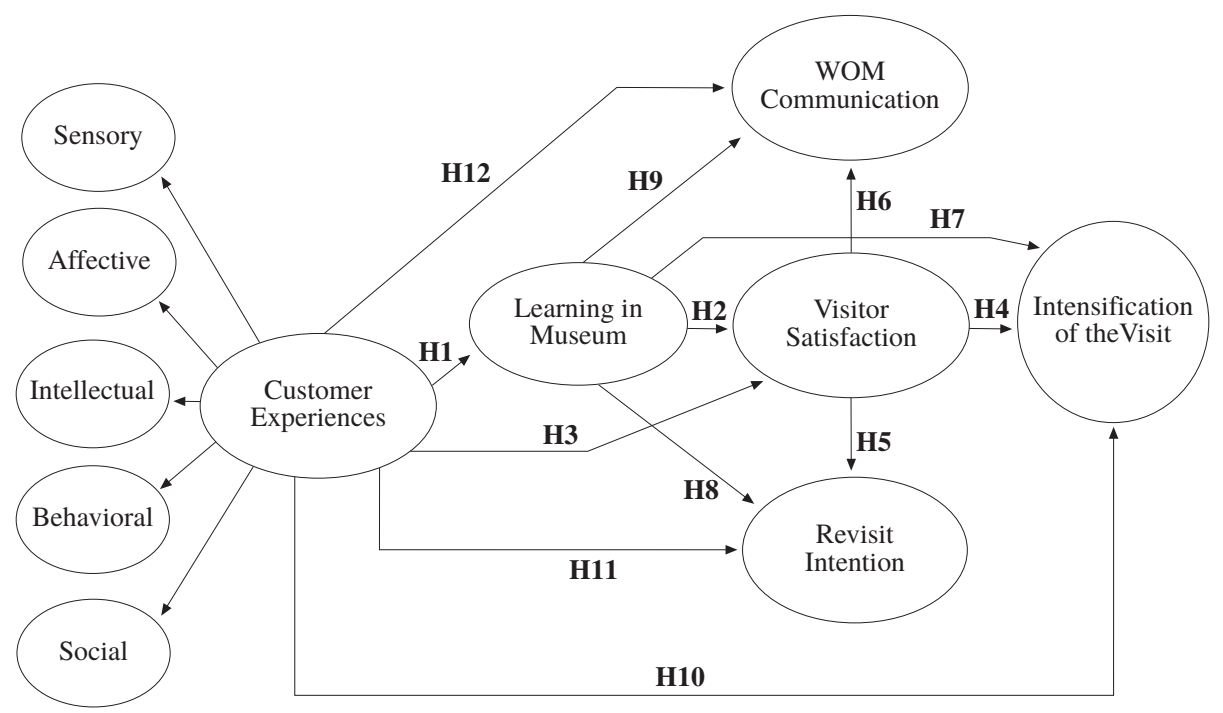


Two types of research are used in this study; an exploratory research and a descriptive research. Exploratory research is used to explore or search through a problem or situation when the researcher has a limited understanding of the research subject (Sekaran, 2003; Malhotra, 2007). This study concerns customer experiences in museums as being an emerging concept; there is limited numbers of studies in the literature. In addition, there is no previous research on this subject in Turkey. Hence, an exploratory study can provide insights and understanding of the museums' customer experiences in Turkey. It is also useful to structure the questionnaire for quantitative research to analyze the proposed model.

In this exploratory research, in-depth interviews with experts are used to obtain qualitative data. The in-depth interview can be defined as an unstructured, direct, oneon-one interview covering underlying motivations, beliefs, attitudes and feelings on a subject (Malhotra, 2007).

The managers of the Magic Ice Museum and the 1453 Panorama Museum agreed to contribute to the exploratory research of this study. The depth interviews were conducted with Volkan Temizkan (operations manager) and Pınar Şahin (marketing specialist) in the Magic Ice Museum on September 29, 2010 and with Salih Doğan (administrative affairs and marketing manager of the Istanbul Metropolitan Municipality's Kültür A.Ş. which operates three museums: the Miniaturk, the Basilica Cistern and the 1453 Panorama Museum) on September 30, 2010. These interviews provided information about the Magic Ice Museum and the 1453 Panorama Museum concerning their customer experience management in Istanbul.

The in-depth interviews reveal that marketing activities in the Magic Ice Museum and the 1453 Panorama Museum are dedicated to creating awareness of their customer's differentiating experiences. They consider also word-of-mouth communication and they urge visitors to revisit the museum to enrich their customer experiences. For instance, the Magic Ice Museum changes all their sculptures made from ice every six months according to different concepts. For the 1453 Panorama Museum, a change in the concept is planned to enrich customer experiences. A planetarium is planned to be built near the museum with themes on knowledge of the sky and universe. Automatic machines are also planned to be placed in different parts of the museum to facilitate different transactions. The information provided by the managers of the Magic Ice museum and the 1453 Panorama Museum supports the classification of museums according to their experiences: museums dynamic in experience and museums static in experience. The dynamism in experience refers to enriching customer experiences.

Based on the literature and the exploratory study, a questionnaire is prepared to collect quantitative data for measuring variables to attain the objectives of the study. A pretest is conducted for the purpose of testing the questionnaire for possible problems such as wording error or incomprehensible questions. Pretesting is the testing of the questionnaire on a small sample of respondents aiming at the improvement of the questionnaire by identifying and eliminating potential problems. The pretest respondents should be from the same population as those of the actual survey. Generally, the pretest sample size is small, varying from 15 to 30 respondents (Malhotra, 2007). The pretest 
was conducted in Istanbul between October 1, 2010 and October 8, 2010 on a sample of 30 people. According to the analysis of the pretest's results, the questionnaire for the study is decided upon for use in the descriptive research.

The prepared questionnaire is distributed to people in Istanbul and the questionnaires of respondents who have not visited the museums indicated are excluded from the study. 460 questionnaires are gathered and used for the analysis.

Quantitative data gathered in the descriptive research are used to analyze a structural model proposed according to the literature review. The independent variables are customer experiences which are sensory, affective, intellectual, behavioral and social. The dependent variables are learning in museums, visitor satisfaction, WOM recommendations, revisit intention and intensification of the visit. The mediating role of learning in museums and visitor satisfaction are analyzed for the effects of independent variables on other dependent variables.

The target population in this study can be defined as visitors of museums dynamic in experience (the Magic Ice, the 1453 Panorama, the Istanbul Toy, the Sakıp Sabanc1, the Rahmi Koç, the Pera, the Istanbul Modern Art and the Miniaturk) in Istanbul who have visited these museums in the past year (November 2009 - November 2010). The sampling frame of this study is students and other people from other occupations who have visited museums dynamic in experience in the past year in Istanbul.

In terms of sample technique, convenience sampling and snowball sampling (nonprobability techniques) are used in this study. Convenience sampling is used to obtain a sample of convenient elements; it is the least expensive and least time consuming sampling technique. In the snowball sampling, subsequent respondents are selected based on the information from the initial randomly selected respondents; its main advantage is that it increases the probability of locating the desired characteristic in the population (Malhotra, 2007). These two sampling techniques are preferred due to the time and budget constraints of this study.

The sample size for this study is decided considering the use of structural equation modeling. A typical sample size in structural equation modeling studies is about 200 cases; however when analyzing a complex model, a sample size of 200 may be too small (Kline, 2010). Multiplying the number of variables by 8 to 15 is enough for a sample size in analysis with structural equation modeling (Acar et al., 2009). According to Kerlinger (1978), sample size should be at least 10 multiplied by variables in the study. So, the sample size for this study is determined by multiplying observed variables to be used in the structural model by ten. Based on this information, in this study with 46 observed variables (item numbers between 9 and 54), a sample size of 460 is decided. As a result, 460 questionnaires were collected between October 10, 2010 and November 5, 2010 by respondents who visited at least one museum dynamic in experience in the past year in Istanbul.

The questionnaire used in the study includes four main parts. The first one is the filtering part. The first and the second questions are filter questions. The questionnaire is excluded from the study if the respondent has not visited a museum in the last year or visited a museum other than those indicated in the second question. Other respondents continue to the following questions choosing a museum according to their degree of satisfaction in the third question. The second part of the questionnaire covers the ques- 
tions between the fourth and eighth questions which are related to the visitors' museum visiting habits. The third part includes the questions to measure museums visitors' customer experiences (sensory, affective, creative cognitive, physical and social identity experiences), learning in the museum, satisfaction, intensifying of visit; revisit intention and word-of-mouth recommendation. This part is formed by structured questions and is measured on a Likert scale basis. The response categories of this scale are "Strongly Disagree," "Disagree," "Neither Agree nor Disagree," "Agree," "Strongly Agree." LISREL is used to generate structural equation modeling including confirmatory factor analyses and relationships between variables.

\section{Research Findings}

The demographic characteristics of the respondents consist of gender, age, monthly income, occupation and education level as indicated in the details of Table 2.

Table 2.

Demographic Characteristics of Respondents

\begin{tabular}{|c|c|c|c|}
\hline & & $\mathbf{N}$ & Percent (\%) \\
\hline \multirow{2}{*}{ Gender } & Women & 263 & 57.2 \\
\hline & Men & 197 & 42.8 \\
\hline \multirow{5}{*}{ Age Groups } & 19 or less & 72 & 15.7 \\
\hline & $20-24$ & 182 & 39.6 \\
\hline & $25-29$ & 102 & 22.2 \\
\hline & $30-34$ & 53 & 11.5 \\
\hline & 35 or more & 51 & 11.1 \\
\hline \multirow{6}{*}{ Monthly Income } & $500 \mathrm{TL}$ or less & 145 & 31.5 \\
\hline & $501 \mathrm{TL}-1000 \mathrm{TL}$ & 104 & 22.6 \\
\hline & $1001 \mathrm{TL}-1500 \mathrm{TL}$ & 88 & 19.1 \\
\hline & $1501 \mathrm{TL}-2000 \mathrm{TL}$ & 58 & 12.6 \\
\hline & $2001 \mathrm{TL}-2500 \mathrm{TL}$ & 30 & 6.5 \\
\hline & $2501 \mathrm{TL}$ or more & 35 & 7.6 \\
\hline \multirow{4}{*}{ Occupation } & Student & 225 & 48.9 \\
\hline & Employee & 169 & 36.7 \\
\hline & Other & 66 & 14.3 \\
\hline & $\begin{array}{l}\text { (employer, self employed, retired) } \\
\text { anunemployed) }\end{array}$ & & \\
\hline \multirow{4}{*}{ Education Level } & Junior High School or below & 32 & 7.0 \\
\hline & High School & 189 & 41.1 \\
\hline & Associate Degree & 118 & 25.7 \\
\hline & Undergraduate or above & 121 & 26.3 \\
\hline Total & Total Respondents & 460 & 100.0 \\
\hline
\end{tabular}


The items measuring customer experiences are first analyzed with a confirmatory factor analysis. Secondly, a confirmatory factor analysis is conducted for post experience dimensions (learning in museum, visitor satisfaction, visit intensifying, revisit intention and WOM recommendation). All the analyses are conducted with a $95 \%$ confidence level.

\section{Confirmatory Factor Analysis for Customer Experience}

Factor analysis is conducted to reduce the number of variables into significant factors bringing together highly correlated variables (Kalayc1, 2008). Factor analysis is an interdependence technique in which a set of interdependent relationships is examined (Malhotra, 2007). The two types of factor analyses are confirmatory factor analysis and exploratory factor analysis. The main difference between them is that confirmatory factor analysis is used to analyze an a priori measurement model with the specified number of factors and their correspondence to the indicators based on theory (Kline, 2010; Şimşek, 2007). However, an a priori hypothesis about factor-indicator correspondence or the number of factors is not a necessity for exploratory factor analysis (Kline, 2010). Structural equation modeling with the LISREL program is used to conduct confirmatory factor analyses (CFA) in this research. The aim in conducting CFA is to analyze the relationships of observed variables (items used in the questionnaire) with latent variables which are customer experiences (sensory, affective, creative cognitive, physical, social identity) and post experience dimensions (learning in the museum, satisfaction, visit intensifying, revisit intention, word-of-mouth recommendation).

For the customer social identity experience, one item is excluded due to its weak factor loading in comparison to the others. In confirmatory factor analyses, it is recommended that there be at least three indicators per factor (Kline, 2010). Thus, customer social identity experience with two items is excluded from the structural equation analyses. CFA is conducted for the rest of the four kinds of customer experiences.

According to the CFA for four customer experiences, some items are eliminated because of low t-values, high standard error, low explained variances and relatively less important variables as indicators of each customer experience. After deleting these items, the first-level CFA is conducted again to be sure that the results fit well ( $\mathrm{p}$ $<0.05$ ). The fit measures indicate that the model is acceptable (Chi-square $=132.99$; df=48; RMSEA=0.062; NFI=0.97; NNFI=0.97; CFI=0.98; AGFI=0.93; SRMR=0.041). Figure 2 provides the details of CFA.

\section{Confirmatory Factor Analysis for Post Experience Dimensions}

A CFA for all post experience dimensions is conducted and some items are eliminated because of low t-values, high standard error, low explained variances and relatively less important variables as indicators of each customer experience. After deleting these items, each construct has three observed variables and the first-level CFA is conducted again to test the model $(\mathrm{p}<0.05)$. The fit measures indicate that the model is acceptable $($ Chi-square $=166.93 ; \mathrm{df}=80 ; \mathrm{RMSEA}=0.049 ; \mathrm{NFI}=0.98 ; \mathrm{NNFI}=0.99 ; \mathrm{CFI}=0.99$; AGFI=0.93; SRMR=0.031).

Table 3 gives information about correlations between post experience dimensions. Detailed CFA results are presented in Table 4. 
Figure 2

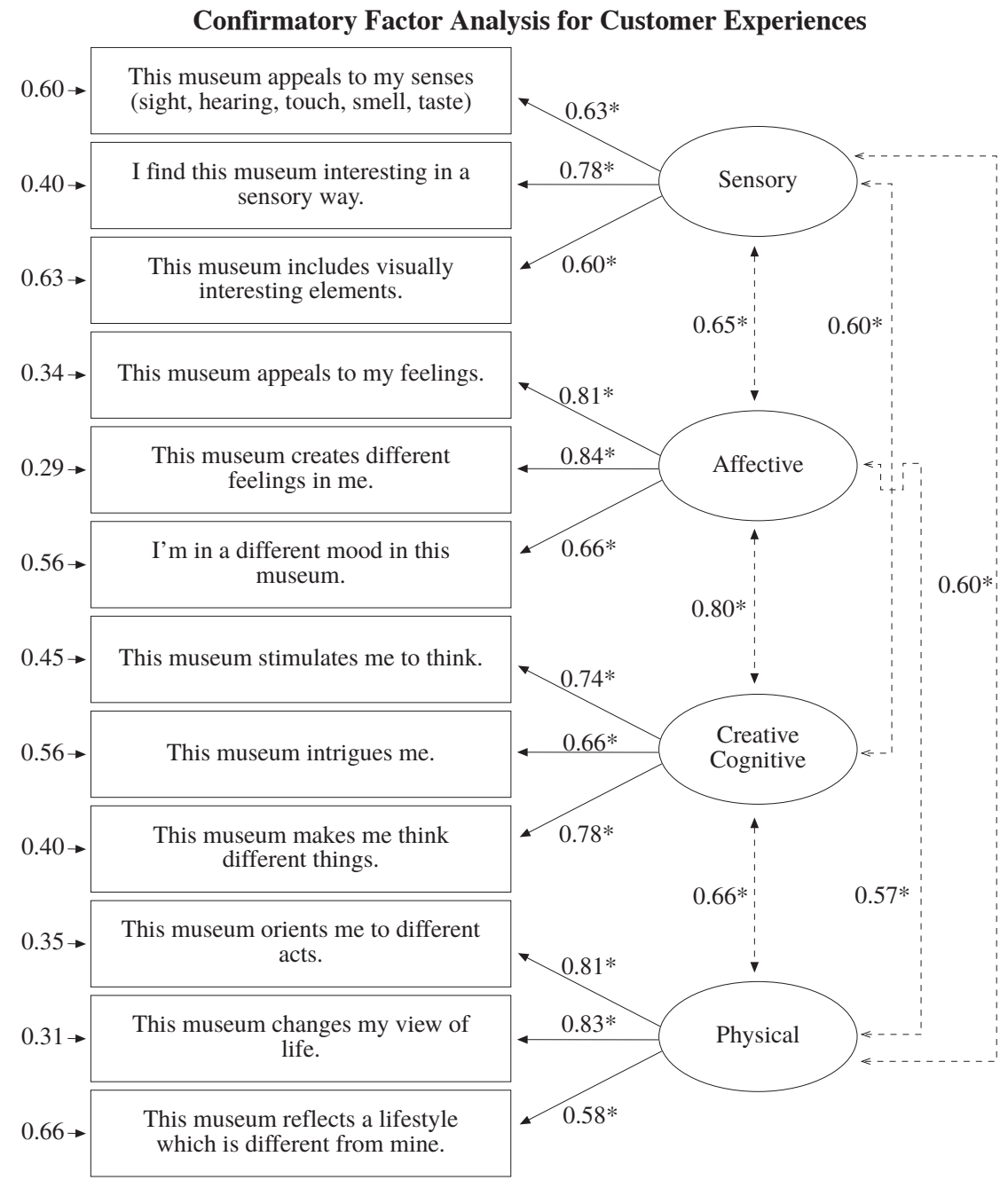

Notes: All coefficient values are standardized and appear near the associated path. Dotted lines represent comelations.

\section{Structural Model for Relationships between Customer Experiences and Post Ex- perience Dimensions}

In the first estimation of the model, $t$-values of the paths from customer experience to visit intensification $(\mathrm{t}=1.58, \mathrm{p}>0.05)$ and from learning to revisit intention $(\mathrm{t}=$ $-0.39, \mathrm{p}>0.05)$ show an insignificance in the parameter value.

After eliminating the insignificant paths, the structural model is reconstructed. The model with 310 degrees of freedom is accepted according to the fit measures indicated in Table 5 ( $\mathrm{p}<0.05)$. The intervals for good fit and acceptable fit are indicated in the study of Engel and Moosbrugger (2003). Fit measures for the structural model are indicated in Table 5 and the structural equation model is shown in Figure 3. 
Table 3.

Correlation Matrix of Post Experience Dimensions

\begin{tabular}{l|l|l|l|l|l}
\hline & $\begin{array}{l}\text { Learning in } \\
\text { Museum }\end{array}$ & $\begin{array}{l}\text { Visitor } \\
\text { Satisfaction }\end{array}$ & $\begin{array}{l}\text { Visit } \\
\text { Intensifying }\end{array}$ & $\begin{array}{l}\text { Revisit } \\
\text { Intention }\end{array}$ & $\begin{array}{l}\text { Word-of-Mouth } \\
\text { Recommendation }\end{array}$ \\
\hline $\begin{array}{l}\text { Learning in } \\
\text { Museum }\end{array}$ & 1 & & & & \\
\hline Visitor Satisfaction & 0.69 & 1 & & & \\
\hline Visit Intensifying & 0.32 & 0.35 & 1 & 1 & \\
\hline Revisit Intention & 0.48 & 0.58 & 0.47 & 0.61 & 1 \\
\hline $\begin{array}{l}\text { Word-of-Mouth } \\
\text { Recommendation }\end{array}$ & 0.66 & 0.77 & 0.39 & & \\
\hline
\end{tabular}

Table 4.

CFA Results for Post Experience Dimensions

\begin{tabular}{|c|c|c|c|}
\hline Latent Variable & Observed Variable & $\begin{array}{l}\text { Standardized } \\
\text { Coefficient } \\
\text { Value }\end{array}$ & $\mathbf{R 2}$ \\
\hline \multirow{3}{*}{$\begin{array}{l}\text { Learning in } \\
\text { Museum }\end{array}$} & I learn many things about the pieces in this museum. & 0.72 & 0.53 \\
\hline & I learn new things in this museum. & 0.86 & 0.74 \\
\hline & I believe that this museum is educational for me. & 0.90 & 0.81 \\
\hline \multirow{3}{*}{$\begin{array}{l}\text { Visitor } \\
\text { Satisfaction }\end{array}$} & I am sure it is the right decision to visit this museum. & 0.84 & 0.70 \\
\hline & In general, I'm satisfied with this visit. & 0.87 & 0.75 \\
\hline & It's worthwhile to visit this museum. & 0.91 & 0.84 \\
\hline \multirow{3}{*}{ Visit Intensifying } & I shop at this museum's store. & 0.80 & 0.63 \\
\hline & $\begin{array}{l}\text { I take some things reminding me of this museum } \\
\text { visit. }\end{array}$ & 0.62 & 0.39 \\
\hline & I take the brochure of this museum. & 0.89 & 0.79 \\
\hline \multirow{3}{*}{ Revisit Intention } & I plan to visit this museum again. & 0.89 & 0.79 \\
\hline & $\begin{array}{l}\text { I think to come back again to this museum in the } \\
\text { future. }\end{array}$ & 0.93 & 0.87 \\
\hline & I go to this museum again on occasion. & 0.83 & 0.69 \\
\hline \multirow{3}{*}{$\begin{array}{l}\text { Word-of-Mouth } \\
\text { Recommen-dation }\end{array}$} & I recommend this museum to others. & 0.91 & 0.84 \\
\hline & $\begin{array}{l}\text { I encourage my friends or relatives to come to this } \\
\text { museum. }\end{array}$ & 0.91 & 0.84 \\
\hline & $\begin{array}{l}\text { I take pride in telling other people about my } \\
\text { experiences in this museum. }\end{array}$ & 0.72 & 0.52 \\
\hline
\end{tabular}


Figure 3

\section{Structural Equation Model of the Study}

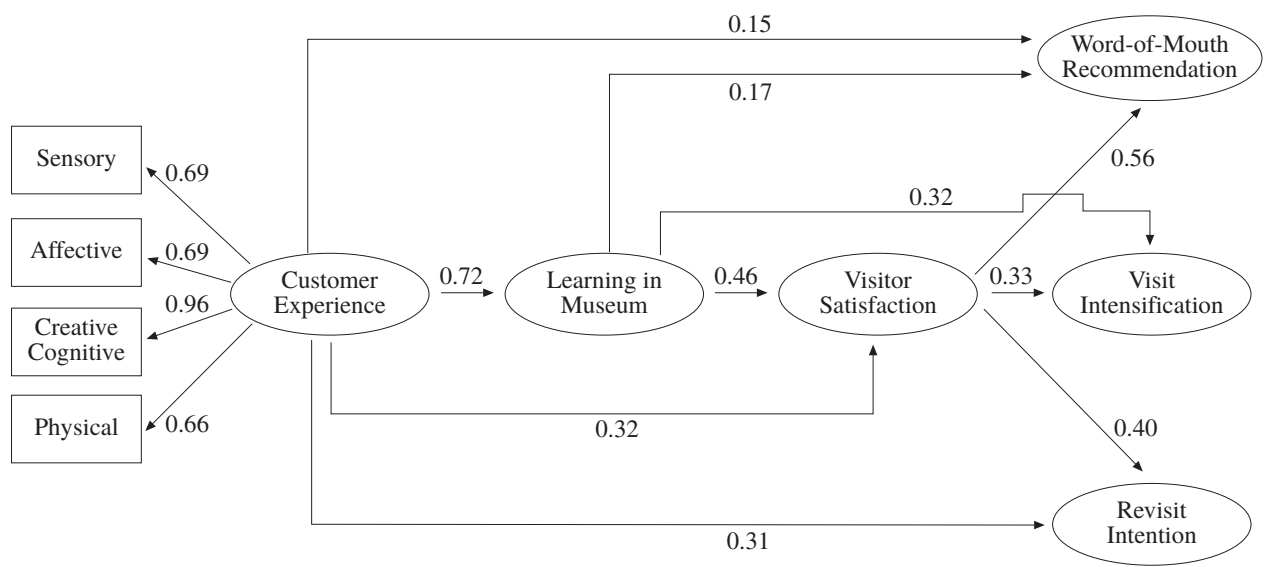

Table 5.

Fit Measures for Structural Model

\begin{tabular}{l|l|l|l}
\hline Fit Measure & Good Fit & Acceptable Fit & Proposed Model \\
\hline$x^{2}$ & $0 \leq x^{2} \leq 2 \mathrm{df}$ & $2 \mathrm{df} \leq x^{2} \leq 3 \mathrm{df}$ & 748.38 \\
\hdashline$x^{2} / \mathrm{df}$ & $0 \leq x^{2} / \mathrm{df} \leq 2$ & $2 \leq x^{2} / \mathrm{df} \leq 3$ & 2.414 \\
\hdashline RMSEA & $0 \leq \mathrm{RMSEA} \leq 0.05$ & $0.05 \leq \mathrm{RMSEA} \leq .08$ & 0.056 \\
\hline SRMR & $0 \leq \mathrm{SRMR} \leq 0.05$ & $0.05 \leq \mathrm{SRMR} \leq .10$ & 0.060 \\
\hline NFI & $0.95 \leq \mathrm{NFI} \leq 1.00$ & $0.90 \leq \mathrm{NFI} \leq 0.95$ & 0.97 \\
\hline NNFI & $0.97 \leq \mathrm{NNFI} \leq 1.00$ & $0.95 \leq \mathrm{NNFI} \leq 0.97$ & 0.98 \\
\hline CFI & $0.97 \leq \mathrm{CFI} \leq 1.00$ & $0.95 \leq \mathrm{CFI} \leq 0.97$ & 0.98 \\
\hline AGFI & $0.90 \leq \mathrm{AGFI} \leq 1.00$ & $0.85 \leq \mathrm{AGFI} \leq 0.90$ & 0.87 \\
\hline
\end{tabular}

\section{Notes:}

$x^{2}$ : Chi-Square Value df: Degrees of Freedom

RMSEA: Root Mean Square Error of Approximation

SRMR: Standardized Root Mean Square Residual

NFI: Normed Fit Index

NNFI: Non Normed Fit Index

CFI: Comperative Fit Index

AGFI: Adjusted Goodness-of-Fit-Index

Source: Adapted from Engel K.S. and Moosbrugger H. (2003). "Evaluating the Fit of Structural Equation Models: Tests of Significance and Descriptive Goodness-of-Fit Measures," Methods of Psychological Research, 8(2): 23-74, p.52. 


\section{Discussion}

This study aims primarily to reveal the relationships between customer experiences and post experience dimensions. All the hypotheses are formed for this purpose. A SEM approach is used to test the hypotheses. To interpret standardized direct effects in SEM, a standardized direct effect smaller than 0.10 may be considered a "smaller" effect, values around 0.30 a "typical" or "medium" effect and values greater than 0.50 a "larger" effect (Kline, 2010).

$\mathbf{H}_{\mathbf{1}}$ : Customer experience has an effect on learning in the museum.

The standardized effect of customer experience on learning in the museum is found to be 0.72 , which indicates a larger effect. So, $\mathrm{H}_{1}$ is supported ( $\left.\mathrm{p}<0.05\right)$.

$\mathbf{H}_{2}$ : Learning in the museum has an effect on visitor satisfaction.

The standardized effect of learning in the museum on visitor satisfaction is found to be 0.46 , which indicates a typical effect. So, $\mathrm{H}_{2}$ is supported ( $\mathrm{p}<0.05$ ).

$\mathbf{H}_{3}$ : Customer experience has an effect on visitor satisfaction.

The standardized effect of customer experience on visitor satisfaction is found to be 0.15 , which indicates a smaller effect. So, $\mathrm{H}_{3}$ is supported ( $\mathrm{p}<0.05$ ).

$\mathbf{H}_{4}$ : Visitor satisfaction has an effect on visit intensification.

The standardized effect of visitor satisfaction on visit intensification is found to be 0.33 , which indicates a typical effect. So, $\mathrm{H}_{4}$ is supported $(\mathrm{p}<0.05)$.

$\mathbf{H}_{5}$ : Visitor satisfaction has an effect on visitor revisit intention.

The standardized effect of visitor satisfaction on visitor revisit intention is found to be 0.40 , which indicates a typical effect. $\mathrm{So}, \mathrm{H}_{5}$ is supported $(\mathrm{p}<0.05)$.

$\mathbf{H}_{6}$ : Visitor satisfaction has an effect on word-of-mouth recommendation.

The standardized effect of visitor satisfaction on word-of-mouth recommendation is found to be 0.56 , which indicates a larger effect. So, $\mathrm{H}_{6}$ is supported $(\mathrm{p}<0.05)$.

$\mathbf{H}_{7}$ : Learning in the museum has an effect on visit intensification.

The standardized effect of learning in the museum on visit intensification is found to be 0.32 , which indicates a typical effect. $\mathrm{So}, \mathrm{H}_{7}$ is supported ( $\mathrm{p}<0.05$ ).

$\mathbf{H}_{8}$ : Learning in the museum has an effect on visitor revisit intention.

The effect of learning in the museum on visitor revisit intention is not significant. So, $\mathrm{H}_{8}$ is not supported ( $\left.\mathrm{p}>0.05\right)$.

$\mathbf{H}_{9}$ : Learning in the museum has an effect on word-of-mouth recommendation. The standardized effect of learning in the museum on word-of-mouth recommendation is found to be 0.17 , which indicates a smaller effect. So, $\mathrm{H}_{9}$ is supported $(\mathrm{p}<0.05)$.

$\mathbf{H}_{\mathbf{1 0}}$ : Customer experience has an effect on visit intensification.

The effect of customer experience on visit intensification is not significant. So, $\mathrm{H}_{10}$ is not supported ( $\mathrm{p}>0.05$ ).

$\mathbf{H}_{11}$ : Customer experience has an effect on visitor revisit intention.

The standardized effect of customer experience on visitor revisit intention is found to be 0.31 , which indicates a typical effect. So, $\mathrm{H}_{11}$ is supported $(\mathrm{p}<0.05)$. 
$\mathbf{H}_{12}$ : Customer experience has an effect on word-of-mouth recommendation. The standardized effect of customer experience on word-of-mouth recommendation is found to be 0.15 , which indicates a smaller effect. So, $\mathrm{H}_{12}$ is supported $(\mathrm{p}<0.05)$.

$\mathbf{H}_{13}$ : Learning in the museum has a mediating role for the customer experiences' effect on visitor satisfaction.

As can be seen in Figure 3, customer experience has both direct and indirect effects on visitor satisfaction. The direct effect is 0.32 and the effect through learning in museum is $0.33(0.72 \times 0.46)$. The total effect of customer experiences on visitor satisfaction is $0.65(0.32+0.33)$. In this case, learning in the museum is the mediating (or intervening) variable. So, $\mathrm{H}_{13}$ is supported $(\mathrm{p}<0.05)$.

\section{Conclusion}

Museums are classically defined as institutions that bring a cultural heritage to people. However, it is important to notice that in recent years they compete with other leisure and educational institutions such as other museums, theatres, cinemas and amusement parks. Thus, museums evolve from a classical assets-focus to a visitor-focus. Nowadays, they offer more experiences to their visitors than they have done before. So, a new categorization is possible for museums: museums dynamic in experience (using experience as a competitive tool) and museums static in experience (offering the natural experience and not improving it to create differentiation). Even though customer experience management has gained ground for museum marketing strategies in the competitive environment, this progress is in the beginning stage; especially in Turkey there are a limited number of museums which are dynamic in experiences.

Parallel to marketing and museum strategies' evolutions, this study reveals the relationships between customer experiences and post experience dimensions. The model developed by this study shows that customer experience affects visitor satisfaction both directly and indirectly through learning in the museum. So, museums may create new experiences not only to satisfy visitors but also to enhance learning in museum. For this purpose, new technologies should be implemented in museums. In particular, Turkish museums' benefits from information communication technologies or RFID technologies are very limited. Special rooms may be developed with 3D films or special machines may be used to print personalized visit plans according to visitors' interests. Using a card system recording the visitors' most visited exhibits may show their interests and special information or gifts sent to them may enhance their experience even outside the museum setting. In addition to the use of technology, for visitors live adventures in museums, scenarios related to the museum subjects should be organized as innovations. In this way, experiential learning is also encouraged beyond visitor satisfaction. According to the model developed in this study, more memorable experience will lead to more satisfied visitors in addition to extended learning. These dimensions lead to word-of-mouth recommendations, visit intensification such as souvenirs and gifts bought from the museum shop and revisiting individuals. 
In terms of the implications for academicians, this study offers a detailed analysis for customer experiences with a museum perspective. This study indicates a structural model including the comparative effects between the dimensions in the museum sector. Depending on this, it reveals the mediating effect of learning between experiences and satisfaction in the museum context.

In summary, the results of this study show clearly that customer experience management plays an important role for customer satisfaction and other post experience dimensions. Thus, marketing plans of organizations should contain customer experience management in order to achieve marketing objectives. Particularly, museums are no longer the places where artifacts are exhibited passively. The managers should develop their visitor-focus with customer experiences to attract more visitors and to satisfy them in the increasingly competitive environment. However, there are limited numbers of studies conducted on customer experiences in Turkey. Academicians should focus on a development of the concept in different sectors and develop the models.

This study is expected to be beneficial for museums' strategies and future studies on customer experiences.

\section{References}

Acar, F., Oğuzlar, A., and Tüzüntürk, S. (2009). "Bayesgil Yapısal Eşitlik Modelleri ve Bir Uygulama Örneği." (Bayesian Structural Equation Models and an Example of Application). 10th Econometrics and Statistics Symposium, (May 27-29). Erzurum.

Aktekin, S. (2008). "Müze Uzmanlarının Okulların Eğitim Amaçlı Müze Ziyaretlerine İlişkin Görüşleri," (The Assessments of Museum Experts for Museum Visits of Schools with the Education Purpose). Ahi Evran Üniversitesi Kırşehir Ĕ̆itim Fakültesi Dergisi (Kefad), 9(2): 103-111.

Anderson, E.W. and Sullivan; M.W. (1993). "The Antecedents and Consequences of Customer Satisfaction For Firms," Marketing Science, 12(2): 125-143.

Arnould, E.J. and Thompson, C.J. (2005). "Consumer Culture Theory (Cct): Twenty Years Of Research," Journal of Consumer Research, 31: 868-882.

Bearden, W.O. and Teel, J.E. (1983). "Selected Determinants of Consumer Satisfaction and Complaint Reports," Journal of Marketing Research, 20: 21-28.

Bergadaà, M. (2005). "Le Musée Olympique: La Structuration D’un Objet Culturel À Caractère Universel À L'aide D'enquêtes Qualitatives." 8th International Conference On Arts And Cultural Management (3-6 July). Montréal: Aimac.

Berry, L.L. (1983). "Relationship Marketing," in L.L. Berry, G.L. Shostack, and G. Upah (eds.). Emerging Perspectives on Services Marketing: 25-28. Chicago, IL: American Marketing Association.

Berry, L.L., Carbone; L.P., and Haeckel, S.H. (2002). "Managing the Total Customer Experience," MIT Sloan Management Review, 43(3): 1-6.

Bifulco, F. and Ilario, A. (2007). "Il Consumatore Culturale Experience-Driven: Evidenze Di Fruizione Del Sistema Museale Napoletano," IV Convegno Annuale Soicetà Italiana Marketing (5-6 Ottobre), Marketing Dei Talenti. Roma: 1-20.

Bigné, J.E., Mattila, A.S., and Andreu; L. (2008). “The Impact of Experiential Consumption Cognitions and Emotions on Behavioral Intentions," Journal of Services Marketing. 22(4): 303-315. 
Bilgin, G. (2010). İstanbul Müzeleri. (Museums of Istanbul). İstanbul: İstanbul Büyükşehir Belediyesi Kültür A.Ş. Yayınları.

Bitgood, S. (1993). "Social Influences on the Visitor Museum Experience," Visitor Behavior. 8(3): 4-5.

Bollo, A. (2004). "Indagine Sul Pubblico Dei Musei Lombardi. Fondazione Fitzcarraldo." Available [online] at: http://www.Fitzcarraldo.It/Ricerca/Pdf/Musei_Lombardia.Pdf (12 August 2010).

Brakus, J.J., Schmitt, B.H., and Zarantonello, L. (2009). "Brand Experience: What is It? How is It Measured? Does It Affect Loyalty?," Journal of Marketing. 73 (May): 52-68.

Caldwell, N.G. (2000). "The Emergence of Museum Brands," International Journal of Arts Management. 2(3): 28-34.

Carù, A. and Cova, B. (2006). "Expériences De Consommation Et Marketing Expérientiel," Revue Française De Gestion. 162: 99-113.

Chang, E. (2006). "Interactive Experiences and Contextual Learning in Museums," Studies in Art Education. 47(2): 170-186.

Chou, H.J. (2009). "The Effect of Experiential and Relationship Marketing on Customer Value: A Case Study of International American Casual Dining Chains in Taiwan," Social Behavior and Personality. 37(7): 993-1008.

Cronin, J.J. and Taylor, S.A. (1992). "Measuring Service Quality: A Reexamination and Extension," Journal of Marketing. 56: 55-68.

Dirsehan, T. (2010). Örneklerle Temel Deneyimsel Pazarlama. (Basic Experiential Marketing with Examples). İstanbul : İkinci Adam Yayınları.

Donald, J.G. (1991). “The Measurement of Learning in the Museum.” Canadian Journal Of Education. 16(3): 371-382.

Engel, K.S. and Moosbrugger, H. (2003). "Evaluating the Fit of Structural Equation Models: Tests of Significance and Descriptive Goodness-of-Fit Measures," Methods of Psychological Research, $8(2): 23-74$.

Evans, J.R. (1997). Production/Operations Management, 5th Edition. St. Paul, Mn: West Publishing Company.

Falk, J.H. and Dierking, L.D. (1992). The Museum Experience. Washington, DC: Howells House.

Fornell, C. (1992). "A National Customer Satisfaction Barometer: The Swedish Experience," Journal of Marketing, 56: 6-21.

Gentile, C., Spiller, N., and Noci, G. (2007). "How to Sustain the Customer Experience: An Overview of Experience Components that Co-Create Value with the Customer," European Management Journal, 25(5): 395-410.

Goulding, C. (1999). "Contemporary Museum Culture and Consumer Behaviour," Journal of Marketing Management. 15: 647-671.

Goulding, C. (2000). “The Museum Environment and the Visitor Experience,” European Journal of Marketing. 34(3/4): 261-278.

Harrison, P. and Shaw; R. (2004). "Consumer Satisfaction and Post-Purchase Intentions: An Exploratory Study of Museum Visitors," International Journal of Arts Management, 6(2): 23-32.

Hein, G. (1999). "The Constructivist Museum," in E.H. Greenhill (ed.). The Educational Role of the Museum, 2nd Edition: 73-79. London: Routledge. 
Hirschman, E.C. and Holbrook, M.B. (1982). Hedonic Consumption: Emerging Concepts, Methods and Propositions. Journal of Marketing. 46: 92-101.

Högström, C., Rosner, M., and Gustafsson, A. (2010). "How to Create Attractive and Unique Customer Experiences: An Application of Kano's Theory of Attractive Quality to Recreational Tourism," Marketing Intelligence and Planning. 28(4): 385-402.

Hume, M., Mort, G.S., Liesch, P.W., and Winzar, H. (2006). "Understanding Service Experience in Non-Profit Performing Arts: Implications for Operations and Service Managemen," Journal of Operations Management, 24: 304-324.

Kalaycı, Ş. (Ed.). (2008). Spss Uygulamalı Çok Değişkenli İstatistik Teknikleri (Multivariate Statistical Technics with Spss Application), 3rd. Edition. Ankara: Asil Yayın Dağıtım.

Kawashima, N. (1998). "Knowing the Public. A Review of Museum Marketing Literature and Research," Museum Management and Curatorship, 17(1): 21-39.

Keith, R J. (1960). “The Marketing Revolution,” Journal of Marketing, 24: 35-38.

Kelly, L. (2004). "Evaluation, Research and Communities of Practice: Program Evaluation in Museums," Archival Science, 4: 45-69.

Kerlinger, F.N. (1978). Foundations of Behavioral Research. New York: Mcgraw-Hill.

Kline, R.B. (2010). Principles and Practice of Structural Equation Modeling, 3rd Edition. New York: The Guilford Press.

Kotler, P., Armstrong, G., Saunders, J., and Wong, V. (1999). Principles of Marketing, 2nd European Edition. New Jersey: Prentice Hall.

Kotler, N.G., Kotler, P., and Kotler, W.I. (2008). Museum Marketing and Strategy: Designing Missions, Building Audiences, Generating Revenue and Resources, 2nd Edition. Jossey-Bass.

Kurtz, D.L. and Boone, L.E. (2010). Principles of Contemporary Marketing, 14th International Edition. South Western.

Lehn, D.V. (2006). “Embodying Experience,” European Journal of Marketing. 40(11/12): 1340-1359.

Malhotra, N.K. (2007). Marketing Research, 5th Edition. New Jersey: Pearson Education.

Maslow, A.H. (1968). Toward a Psychology of Being, 2nd Edition. N.J.: Van Nostrand.

McCarthy J. and Ciolfi, L. (2008). "Place as Dialogue: Understanding and Supporting the Museum Experience," International Journal of Heritage Studies, 14(3): 247-267.

Meyer C. and Schwager, A. (2007). "Understanding Customer Experience," Harvard Business Review, February: 1-12.

Mottner, S. and Ford, J.B. (2005). "Measuring Nonprofit Marketing Strategy Performance: The Case of Museum Stores," Journal of Business Research, 58: 829-840.

Oh, H., Fiore, A.M., and Jeoung, M. (2007). "Measuring Experience Economy Concepts: Tourism Applications," Journal of Travel Research. 46: 119-132.

Oliver, R.L. (1981). "Measurement and Evaluation of Satisfaction Processes in Retail Settings," Journal of Retailing, 57(3): 25-48.

Packer J. and Ballantyne, R. (2002). "Motivational Factors and the Visitor Experience: A Comparison of Three Sites," Curator, 45(3): 183-198. 
Petkus E. Jr. (2004). "Enhancing the Application of Experiential Marketing in the Arts," International Journal of Nonprofit and Voluntary Sector Marketing, 9(1): 49-56.

Pine II, B.J. and Gilmore, J.H. (1998). "Welcome to the Experience Economy," Harvard Business Review, 76(4): 97-105.

-----, (1999). The Experience Economy: Work is Theatre and Every Business a Stage. Boston, MA: Harvard Business School Press.

Prentice, R., Davies, A., and Beeho, A. (1997). "Seeking Generic Motivations for Visiting and Not Visiting Museums and Like Cultural Attractions," Museum Management and Curatorship, 16(1): 45-70.

Rojas, M.C. and Camarrero; M.C. (2006). "Experience and Satisfaction of Visitors to Museums and Cultural Exhibitions," International Review on Public and Non Profit Marketing, 3(1): 49-65.

Rowley, J. (1999). “Measuring Total Customer Experience in Museums," International Journal of Contemporary Hospitality Management, 11(6): 303-308.

Schmitt, B. (1999). “Experiential Marketing,” Journal of Marketing Management, 15: 53-67.

Sekaran, U. (2003). Research Methods for Business: A Skill Building Approach, 4th Edition. John Wiley and Sons.

Sezgin, M. and Karaman, A. (2009). Müze Yönetimi ve Pazarlaması (Management and Marketing of Museums). Konya: Çizgi Kitabevi.

Shaw, C. (2007). The Dna of Customer Experience, How Emotions Drive Value. New York: Palgrave Macmillan.

Slater, A. (2007). "Escaping to the Gallery: Understanding the Motivations of Visitors to Galleries," International Journal of Nonprofit and Voluntary Sector Marketing, 12: 149-162.

Şimşek, Ö.F. (2007). Yapısal Eşitlik Modellemesine Giriş: Temel İlkeler ve Lısrel Uygulamaları (Introduction to Structural Equation Modeling: Basic Principles and Lisrel Applications). Ankara: Ekinoks.

Thyne, M. (2001). "The Importance of Values Research for Nonprofit Organizations: The MotivationBased Values of Museum Visitors," International Journal of Nonprofit and Voluntary Sector Marketing, 6(2): 116-130.

Tucker, R.B. (1991). “Ten Driving Forces of Dynamic Change,” Executive Excellence. 8(3): 16.

Woodside, A.G., Frey, L.L., and Daly, R.T. (1989). "Linking Service Quality, Customer Satisfaction, and Behavioral Intention," Journal of Health Care Marketing, 9(4): 5-17.

Yalçın, M. (2009). İnovasyonla Hizmet ve Deneyim (Innovative Services and Experiences). İstanbul: Yaprak Yayın Dağıtım.

Yucelt, U. (2000). "Marketing Museums: An Empirical Investigation among Museum Visitors," Journal of Nonprofit and Public Sector Marketing, 8(3): 3-13.

Zarantonello, L. (2008). "L'adattamento Della Brand Experience Scale Al Mercato Italiano," Mercati E Competitività, 3: 109-132.

Zeithaml V.A., Berry, L.L., and Parasuraman, A. (1996). "The Behavioral Consequences of Service Quality," Journal of Marketing, 60: 31-46.

Zeithaml, V.A., Bitner, M.J., and Gremler, D.D. (2009). Services Marketing: Integrating Customer Focus across the Firm, 5th International Edition. Singapore: McGraw Hill. 